\title{
The Relationship of Self-Efficacy Toward Student's Achievement Index of Faculty of Teacher Training and Education at Malikussaleh University
}

\author{
Faradhillah ${ }^{1, a^{*}}$, Izkar Hadiya ${ }^{1, b}$, dan Nuraini Fatmi ${ }^{1, c}$ \\ 1Department of Physics Education, Malikussaleh University, Aceh Utara, 24355, Indonesia \\ a faradhillah_08@yahoo.com; b izkar_hadiya@unimal.ac.id; c nurainifatmi@unimal.ac.id \\ ${ }^{*}$ Corresponding Author \\ Whatsapp number: [+62 852-7788-6130]
}

How to Cite : Faradhillah, F., Hadiya, I., Fatmi, N. (2020). The Relationship of Self-Efficacy Toward Student's Achievement Index of Faculty of Teacher Training and Education at Malikussaleh University. International Journal for Educational and Vocational Studies, 2 (1), 139-142. DOI: https://doi.org/10.29103/ijevs.v2i1.2121

\section{ARTICLE HISTORY}

Received: 18 December 2019

Revised: 27 December 2019

Accepted: 26 January 2020

\section{KEYWORDS}

Self-Efficacy;

Student's Achievement Index;

Faculty of Teacher Training and Education;

Malikussaleh University;

\section{ABSTRACT}

This study aims to determine the relationship between Self-Efficacy on Student's Achievement Index. This study is a quantitative research type ex post facto. The study sample was determined by proportionate cluster random sampling. Study data consisting of student self-efficacy data and student's academic achievement index data were each tested for their homogeneity and normality using SPSS and it was found that the data distribution was normal and homogeneous. Data that has been tested for homogeneity and normality are then tested for correlation with the Pearson correlation test obtained results of 0.62 with a significance of $0.0641<0.05$ ie there is a strong relationship between student Self-Efficacy with student achievement index or it can be mentioned that there is no significant relationship between Self-Efficacy with the academic achievement index of Faculty of Teacher Training and Education at the Malikussaleh University in the 2018/2019 academic year.

This is an open access article under the CC-BY-SA license.

\section{INTRODUCTION}

Benchmarks for learning success at all levels is the achievement of the value of learning outcomes. At the elementary, junior high and high school education levels, it can be seen from the report cards that are reports of achievement of learning outcomes, while at the tertiary level, the benchmark for the learning process is the Achievement Index (IP). Performance index is one of the benchmarks in the form of a number / value of a student's achievement in academics. The higher the achievement index of a student, the more successful the student is in the academic field.

The success of students in the academic field is influenced by many factors. Broadly speaking, there are two main factors that influence success in the academic field, namely internal and external factors. Internal factors are factors that are within the individual, while external factors are factors that are outside the individual (Slameto, 2010). Included in internal factors are intelligence or intelligence, talent, attention, interest, motivation, maturity, and readiness, while those included in external factors are family environment, school/campus environment, and community environment.

Internal factors and external factors support each other in the academic success of students. cognitive abilities that are included in internal factors alone cannot guarantee a student succeed in achieving achievement, many students have high cognitive abilities but he does not have good performance, conversely there are students who have cognitive abilities that are not too high but can have good achievements .

Many other factors besides cognitive abilities affect student achievement, including factors related to courage and self-confidence in the abilities of individuals. A person's confidence in their ability to achieve achievement is known as self efficacy.

Bandura (1997) states that, "self-efficacy as one's belief in his ability to organize and carry out actions to achieve the goals set", therefore self-efficacy also contributes to determine how well learning achievement can be achieved by individual. Furthermore Santrock 
(2009) revealed that, "self-efficacy is one of the most important factors in determining whether students perform or not".

Based on the results of preliminary observations that the author has done in several classes of students of the 2016 FKIP Faculty of Malikussaleh University, there are various conditions. There are some students who are not sure and confident. This can be seen when the writer asks students to answer questions, students tend to be passive and do not want to answer questions that the authors ask even though these students can actually answer the question.

Some other students actually show their attention in the learning process, this is contrary to the conditions above. In addition, these students have confidence and confidence in themselves. They are more active and dominating in the learning process that occurs in the classroom. This condition is seen when they scramble to answer the questions raised. In addition, they also have the enthusiasm to follow every learning process and complete every task given by the Lecturer. They do not give up easily and instead feel challenged to complete the task. This situation is in accordance with the opinion of Ormrod (2008) which states that "individuals who have high self efficacy are more likely to exert all their energy and do not give up when facing difficulties. In addition, Bandura (1997) in Ormrod (2008: 23) also revealed that ", high self-efficacy is useful to encourage individuals to do challenging activities".

Self Efficacy is an assessment of yourself, about whether being able to do good or bad actions, right or wrong, can or can not do in accordance with predetermined criteria. Self-efficacy is different from ideals, because the ideals show something that should be, while self-efficacy shows an assessment of self-ability (Alwisol, 2012). Baron and Byrne (in Ghufron \& Rini, 2010) define that ", self-efficacy is an evaluation someone about his ability or competence to do a task, achieve a goal, and overcome an obstacle.

Meanwhile, according to Bandura and Wood in Mustaqim (2008) states that, "Self Efficacy is a belief in one's ability to move motivation, cognitive resources, and a series of actions needed to meet the demands of the situation at hand.

Someone who has high self efficacy believes that they are able to change the events around him while someone with low self-efficacy considers himself unable to do something around him. In difficult conditions people who have low self-efficacy will easily give up, while people who have high self-efficacy will try to overcome the existing problems. This is consistent with the opinion of Bandura (1991) which states that ", individuals who have high self-efficacy will achieve a better performance, because these individuals have strong motivation, clear goals, and stable emotions, and their ability to provide performance on activities or behaviors with success ".
Whereas individuals with low self-efficacy prefer not to try to be alone or prefer cooperation in difficult situations and high levels of task complexity.

Bandura (1997) states that self-efficacy consists of 3 stages:

a. Level/magnitude, at the level/magnitude stage is related to the level of difficulty of the task. This stage refers to the level of difficulty of the task that the individual believes will be able to overcome it,

b. Strength, the strength stage refers to the strength of an assessment of individual abilities. This stage is with the degree of stability of the individual against the beliefs they make. This stability determines the resilience and tenacity of the individual in the business. This stage is an individual's belief in maintaining certain behaviors,

c. Generality, generality stage is a concept that states that one's self efficacy is not limited to specific situations. This stage refers to variations in situations where an assessment of self efficacy can be applied.

In the context of education, self-efficacy must be possessed by every student so that they have confidence in their abilities so that no matter how difficult the material or exam questions, they are confident they can solve them. In addition, self efficacy encourages students to be more mature as a form of preparation to face challenges. This is in line with the opinion expressed by Schunk and Frank (2012) namely:

"Student who feel more efficacious about learning should be more apt to engage in self-regulation (e.g., set goals, use effective learning strategies, monitor their comprehension, evaluate their goal progress) and create effective environments for learning (e.g., eliminate or minimize distraction, find effective study partners)". in turn, self-efficacy canbe influenced by the outcomes of behaviors (e.g.,goal progress, achievment)and by input for the environment (e.g., feedback from teachers, social comparisons with peers)"

\section{METHODS}

\subsection{Type and Location of Research}

This research is a quantitative research with ex post facto research type because this research is about variables that occur before the research has been carried out. The location of the study was at the Faculty of Teacher Training and Education (FKIP) Malikussaleh University.

\subsection{Population and Sample}

The population in this study consisted of 60 students who were students from 2016, 2017 and 2018. How to determine the sample size in this study using an error rate of $5 \%$ with a population size of 340 . Based on the table determining the sample size of certain populations with an error rate of $5 \%$ (Sugiyono, 2010) this study has a 
population of 1200 so that based on the table size determination the sample is obtained as many as 60 samples. The sampling technique uses proportionate cluster random sampling technique.

\subsection{Research procedure}

This research was carried out through three stages, namely: the preparatory stage, the implementation phase, and the final stage.

\subsubsection{Activity Preparation Phase conducted at this stage are:}

a. Communicate with the head of the Physics, chemistry and mathematics education study program to ask permission to carry out research.

b. Develop a Self Efficacy questionnaire. The Self Efficacy Questionnaire is composed of 50 statement items with the following details: Difficulty level (level) consists of 20 items, Strength level consists of 15 items and Generality consists of 15 items

\subsubsection{Stages of implementation}

At this stage the self-efficacy questionnaire began to be distributed

\subsubsection{Final stages}

After all research activities have been carried out, an analysis of the data obtained has been carried out to determine the extent to which the objectives of the research carried out were answered.

\section{RESULTS AND DISCUSSION}

\section{Results}

\subsection{Normality test results}

\subsection{Homogeneity test results}

Test of Homogeneity of Variances

\begin{tabular}{|c|c|c|c|}
\hline Levene Statistic & df1 & $\mathrm{df} 2$ & Sig. \\
\hline .599 & 2 & 56 & .553 \\
\hline
\end{tabular}

Test of Homogeneity of Variances

IPK Value

\begin{tabular}{rrrrr}
\hline Levene Statistic & df1 & & df2 & Sig. \\
\hline .641 & & 2 & 56 & .530 \\
\hline
\end{tabular}

Because the significance value obtained is 0.553> $0.05,0.530>0.05$, the variance of the data groups is the same.

\subsection{Pearson correlation test}

Correlations

\begin{tabular}{llrr}
\hline & & Self-Efficacy & \multicolumn{2}{c}{ IPK value } \\
\hline \multirow{3}{*}{$\begin{array}{l}\text { Self-Effica } \\
\text { cy }\end{array}$} & Pearson Correlation & 1 & .62 \\
\cline { 2 - 4 } & Sig. (2-tailed) & & .641 \\
\cline { 2 - 4 } & $\mathrm{N}$ & 60 & 60 \\
\hline \multirow{3}{*}{ nilai ipk } & Pearson Correlation & .62 & 1 \\
\cline { 2 - 4 } & Sig. (2-tailed) & .641 & \\
\cline { 2 - 4 } & $\mathrm{N}$ & 60 & 60
\end{tabular}

Correlation between Self-Efficacy with IPK obtained coefficient value of 0.62 , because the coefficient approaching number 1 shows a strong correlation. Then in terms of significance obtained a value of $0.0641<0.05$, it can be concluded that there is a significant relationship between Self-Efficacy and IPK values.

The number $\mathrm{R}$ shows a simple correlation (Pearson correlation) between the variables $\mathrm{X}$ and $\mathrm{Y}$. The number $\mathrm{R}$ obtained is 0.62 , this means the relationship between self efficacy with a strong IPK because the value approaches the number 1 .

\section{Discussion}

Based on the results obtained from the statistical analysis, it can be concluded that student's self efficacy has a strong relationship or gives an effect on IPK or student academic achievement.

There are a lot of supporting research which states that self efficacy has an influence on academic achievement as mentioned in the research of Handayani and Desi N (2013), Majidah et al. (2013), Nugroho (2007), and Muhyadin et al (2006).

One-Sample Kolmogorov-Smirnov Test

\begin{tabular}{llrr}
\hline & & Self-Efficacy & \multicolumn{1}{l}{ IPK value } \\
\hline $\mathrm{N}$ & & 60 & 60 \\
\hline \multirow{2}{*}{ Normal Parametersa,b } & \multicolumn{1}{l}{ Mean } & 73.5000 & 3.5967 \\
\cline { 2 - 4 } & Std. Deviation & 4.97962 & .18925 \\
\hline \multirow{2}{*}{$\begin{array}{l}\text { Most Extreme } \\
\text { Differences }\end{array}$} & Absolute & .142 & .109 \\
\cline { 2 - 4 } & Positive & .134 & .107 \\
\cline { 2 - 4 } & Negative & -.142 & -.109 \\
\hline Kolmogorov-Smirnov Z & & 1.101 & .842 \\
\hline Asymp. Sig. (2-tailed) & & .177 & .478 \\
\hline
\end{tabular}

a. Test distribution is Normal.

\section{a. Calculated from data. \\ b.}


Bandura (1997) states that self-efficacy is a belief in a person's ability to organize and execute a program of actions needed to produce a given achievement, the cause of the initiation of behavior, the amount of effort expended, persistence despite experiencing obstacles and the end of success. Someone who has self efficacy tends to have resistance to adversity.

Self-Efficacy is a specific aspect that must be measured in terms of certain assessments of abilities that might differ from task demands in one aspect of a particular activity as well as under different circumstances. Self efficacy determines how to feel, think, and motivate in doing an action. A person's ability to overcome problems is influenced by the achievements he has previously achieved, so that someone who tends to lose, because it is always wrong.

The results obtained in this study differed from a number of previous studies due to the average student having a self-efficacy of 73 or being in the moderate category. This affects the learning styles of students who tend to complete assignments together so that the average student has a IPK of 3.59 with the lowest IPK of the sample being 3.21 and the highest of 3.94. Students who have a IPK of 3.21 have a self-efficacy of 71 while those who have a IPK of 3.94 have a self-efficacy of 76. Students who have the highest self-efficacy of 87 have a IPK of 3.65 while students who have a self-efficacy of 64 have a IPK of 3.58. So it can be concluded the reason why the correlation was obtained for 0.62 there is strong and significant relationship between self-efficacy and IPK.

Learning in higher education institutions tends to require students to collaborate so that the academic achievements achieved do not reflect the true abilities of students. Even an evaluation of the lecture process was still found by students who collaborated in solving evaluation questions. Students also tend to have different interests in various subjects which ultimately make the final grades obtained complementary.

Novferma (2016) states that students' beliefs and perceptions about the subject being studied have an effect on student achievement in learning. Schunk (2012) states that self-efficacy refers to one's view of one's ability to perform certain actions, while outcome expectation refers more to beliefs about the results to be obtained from these actions.

Many factors make the results of this study biased. So that improvements are needed for example by conducting research that further reduces the intensity that produces bias, for example by limiting the scope of achievement to only one course, and one class of students. achievements.

Self-efficacy will also continue to be fostered to those who have achieved success to add success to the next, while those who fail self-efficacy will continue to decline so that makes them despair in producing achievements.

\section{REFERENCES}

Alwisol. (2012). Psikologi Kepribadian (Edisi Revisi). Malang: Umm Press

Bandura, A. (1991). Social Cognitive Theory of Self Regulation. Organizational Behavior and Human Decision Processes, 50(2), 248-287

Bandura, A. (1997). Self Efficacy- The Exercise of Control (Fifth Printing, 2002), Newyork:W.H. Freeman \& Company.

Ghufron, M. Nurdan Rini Risnawati. (2010). Teori-teori Psikologi. Yokyakarta: Ar-Ruzz Media

Handayani, F.and Desi Nurwidawati. (2013). Hubungan Self Efficacy dengan Prestasi Belajar Siswa Akselerasi. Character. Volume 01. No 02.

Mahyuddin, Rahil, Habibah, Elias, LohSau Cheng, Muhd. Fauzi Muhammad, Noorem Nurdindan Maria Chong Abdullah. (2006). The Relationship Between Students' Self Efficacy and Their English Language Achievement. Jurnal Pendidik dan Pendidikan. Jilid 2.

Majidah, Hairida. Erlina. (2013). Korelasi antara Self-Efficacy dengan Hasil Belajar Siswa dalam Mata Pelajaran Kimia SMA. Skripsi. Program StudiPendidikan Kimia. FKIP Untan

Mustaqim. (2008). Psikologi Pendidikan. Yokyakarta: PustakaPelajar Offset

Novferma, N. (2016). Analisis Kesulitan dan Self-efficacy Siswa SMP dalam Pemecahan Masalah Matematika Berbentuk Soal Cerita. Jurnal RisetPendidikan Matematika. Vol.3, No.1 hal. (76-87)

Nugroho, O.A. (2007). Hubungan antara Self-Efficacy, Penyesuaian Diri dengan Prestasi Akademik Mahasiswa Jurusan Bimbingan Konseling FKIP Universitas Widya Mandala Madiun

Ormrod, J.E. (2008). Psikologi Pendidikan Jilid 1. Jakarta: Erlangga

Santrock, J.W. (2009). Psikologi Pendidikan (edisi tiga, jilid 2). Jakarta: Salemba Humanika

Schunk, D.H. (2012). Learning Theories (6 ${ }^{\text {th }}$ ed.). Boston. MA: Pearson Education. Inc.

\section{CONCLUSION}

Self-efficacy has a strong relationship with student achievement index when viewed in individual achievements in the academic field. High self-efficacy will support student success because with high self-efficacy students are more willing to achieve even the most difficult 